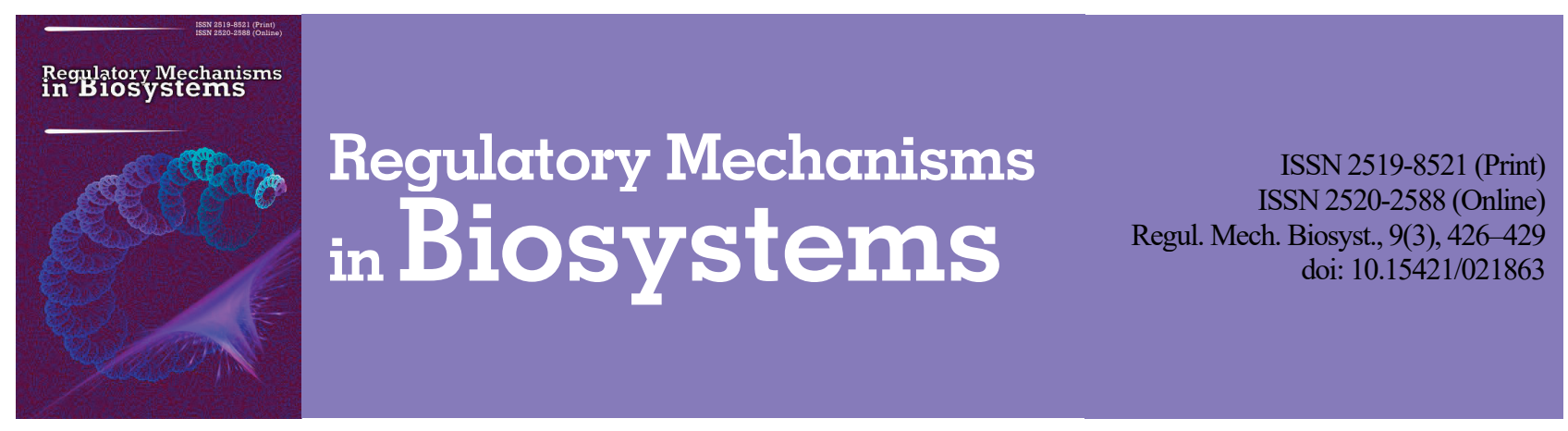

\title{
Choosing selective factors for the cultivation of Aerococcus viridans symbiont strains
}

\author{
D. O. Stepanskyi, I. P. Koshova, G. M. Kremenchutskyi, O. V. Khomiak \\ SE "Dnepropetrovsk Medical Academy of Ministry of Health of Ukraine", Dnipro, Ukraine
}

\author{
Article info \\ Received 15.06.2018 \\ Received in revised form \\ 23.07.2018 \\ Accepted 28.07.2018
}

SE "Dnepropetrovsk Medical Academy of Ministry of Health of Ukraine", Vernadsky st., 9 , Dnipro, 49000, Ukraine. Tel.: +38-067-797-84-97.

E-mail:dstepanskiy@gmail.com

\author{
Stepanskyi, D. O., Koshova, I. P., Kremenchutskyi, G. M., \& Khomiak, O. V. (2018). Choosing selective factors for the \\ cultivation of Aerococcus viridans symbiont strains. Regulatory Mechanisms in Biosystems, 9(3), 426-429. doi:10.15421/021863
}

Aerococci have certain cultivation characteristics. A well-known method of aerococcal cultivation uses indicator media which included the complex "oxolinic acid - etonium", but data indicating cases of conditionally pathogenic flora contamination due to the accumulation of microorganisms that are resistant to this complex have been obtained. Therefore, there was a need to search for new substances that would have a wide range of antagonistic activity in relation to the conditionally pathogenic flora and at the same time would not inhibit the growth of aerococci, and which would also be available and safe. The sensitivity of the $A$. viridans symbionts and conditionally pathogenic flora to the substances with antimicrobial activity of different groups was determined by the method of "wells". For research, A. viridans symbionts isolated from different microbiocenoses have been used. $P$. aeruginosa, $S$. aureus, $K$. pneumoniae, $E$. coli and $C$. albicans were used as conditionally pathogenic flora. Norfloxacin, pefloxacin, ofloxacin, gatifloxacin, levofloxacin, miramistin, decamethoxine, chlorhexidine, octenidine and boric acid were used as investigational drugs. Also, the optimal concentration of drugs which would suppress the growth of conditionally pathogenic flora, and would not show a negative effect on $A$. viridans was determined by serial dilutions. It was found that miramistin, norfloxacin and boric acid meet the necessary criteria. The serum dilutions method was used to determine the minimum inhibitory concentration (MIC) of these drugs in the experiment. Norfloxacin in a dosage of $12.5-50.0 \mu \mathrm{g} / \mathrm{ml}$ effectively inhibited the growth of the conditionally pathogenic flora, but also reduced the number of aerococci. The dose of $8.3 \mu \mathrm{g} / \mathrm{ml} \mathrm{met} \mathrm{the} \mathrm{criteria} \mathrm{we} \mathrm{needed,}$ namely suppressing the growth of the conditionally pathogenic flora and not affecting aerococci. The concentration of miramistin and boric acid in a culture medium that showed a stong depressant effect on conditionally pathogenic flora and practically did not affect $A$. viridans was $50 \mu \mathrm{g} / \mathrm{ml}$. In addition, miramistin and boric acid exhibited fungicidal action against $C$. albicans. Antimicrobial effects of the investigated drugs on the conditionally pathogenic flora was not complete in some cases, or inhibited the growth of aerococci at higher doses, so the effect of their rational combination on the conditionally pathogenic flora was investigated. As a result, an antimicrobial complex with optimal concentrations of substances (norfloxacin $8.3 \mu \mathrm{g} / \mathrm{ml}$, myramistin $50 \mu \mathrm{g} / \mathrm{ml}$, boric acid $50 \mu \mathrm{g} / \mathrm{ml}$ ), which effectively suppresses UPMF and does not affect the growth of symbionic $A$. viridans, was determined. The specified antimicrobial complex can be used for the production of modified media for isolation, cultivation and study of biochemical activity of $A$. viridans microorganisms. Properties of aerococci, grown on the nutrient medium with the studied drugs did not differ from aerococci, grown on nutrient media without additives.

Keywords: aerococci; autosymbionts; cultivation of aerococci; indicator media; modified media.

\section{Introduction}

Aerococcus viridans is a bacterium that is present in the environment and was initially isolated from the air. Other types of Aerococcus have been obtained from different parts of the human body and animals (Collins et al., 1999; Nobukazu Saishu et al., 2009). Aerococci are components of normal gut microbiota of animals (Wise \& Siragusa, 2007; Senneby et al., 2016) and human intestinal flora. Along with this, there are cases of allocation of aerosols in humans and animals in various pathologies and these are associated, as a rule, with immuno-deficiency states. Initially, the Aerococcus genus, which included a single species Aerococcus viridans was described. Subsequently, five new Aerococcus species: Aerococcus urinae, A. sanguinicola, A. christensenii, A. urinaeequi and A. urinaehominis (Facklam\&Elliot, 1995) have been identified. The clinical significance of these species was clearly established for A. urinae and A. viridans (Shelton-Dodge et al., 2011; Rasmussen et al., 2013; Humphries et al., 2014; Senneby et al., 2015).

A. viridans are ubiquitous microorganisms, and have certain peculiarities of cultivation (Williams \& Hirch, 1953; Rizhenko et al., 2002; Facklam et al., 2003). Research carried out used displaying medias through which the allocation, identification and differentiation of aerococci were conducted (Good et al., 1966; Devrise et al., 1999; Kremenchuckij et al., 2003, 2009). The composition of the aforementioned media for the selective allocation of various types of aerococci included the complex "oxolinic acid - etonium", which gave a selective effect of predominant aercocci growth in concentrations: oxalic acid $50 \mu \mathrm{g} / \mathrm{ml}$, etonium $-5 \mu \mathrm{g} / \mathrm{ml}$. In the process of use of these media, data indicating cases of conditionally pathogenic flora (CPF) contamination due to the accumulation of microorganisms that are resistant to the "oxolinic acid - etonium complex" were obtained. The above-mentioned facts and increased incidence of infections caused by hospital strains with multi-resistance to chemotherapy (Uh et al., 2002; Yasukawa et al., 2014; Gonzalez et al., 2017), especially methicillin-resistant Staphylococcus aureus (MRSA) (Cho \& Chung, 2017), have also created a need to search for new substances that would have a wide range of antagonistic activity in turn on the $\mathrm{CPF}$ and inhibit the growth of aerococci at the same time and which should also be accessible and safe.

The experimental method (Stepanskyi \& Kremenchutskyi, 2014) made it possible to discover the sensitivity of the $A$. viridans symbionts to fluoroquinolones and determined that norfloxacin at a dosage of $8.3 \mu \mathrm{g} / \mathrm{ml}$ practically did not affect the growth of aerococci and effectively suppresses the CPF. However, it was important to enhance the 
selective effect of norfloxacin with other antimicrobial agents in order to receive stronger suppression of CPF. Therefore, the purpose of the study was to select a selective antibacterial complex that would suppress the growth of UPMF and would not affect the growth of $A$. viridans, with the possibility of using it for the production of modified media for isolation, cultivation and study of the biochemical activity of $A$. viridans microorganisms.

\section{Materials and methods}

The determination of the $A$. viridans symbionts and CPF sensitivity to the substances of different groups with antimicrobial activity was carried out by the method of "wells" (Habriev, 2005; CLSI, 2010). As a dense nutrient medium, the Mühler-Hinton agar was used, in which the wells with a diameter of $8 \mathrm{~mm}$ were used, the "lawn" was sown with test strips and the test specimens $(0.01 \mathrm{ml})$ were placed. The inoculation was incubated at $37^{\circ} \mathrm{C}$ for 24 hours. The results of the experiment were recorded by measuring the diameter of the growth inhibition zone in $\mathrm{mm}$.

$A$. viridans symbionts isolated from different human and animal microbiocenoses were used for the study: A. viridans E34 (human intestine), A. viridans $\mathrm{O} 36$ (human oral cavity ), A. viridans $5 \mathrm{~m} 2015$ (mouse feces), A. viridans 3k2015 (rat feces), A. viridans 23 (human tonsils). As CPF, Pseudomonas aeruginosa ATCC 27853, Staphylococcus aureus 209-p, Klebsiella pneumoniae ATCC 700603, Escherichia coli ATCC 8739 and Candida albicans ATCC 885-653 were taken. Norfloxacin, pefloxacin, ofloxacin, gatifloxacin, levofloxacin, miramistin, decamethoxine, chlorhexidine, octenidine, boric acid were used as investigational drugs. The number of studies was 5 for each microorganism.

After determining the optimal, in terms of the purpose of the study, drugs, in order to minimize selective factors in nutrient media for growing aerococci, the optimal concentration of drugs was determined by the method of serial dilutions, which would suppress the growth of CPF, and would not show a negative effect on $A$. viridans. For inoculation, a standard microbial suspension equivalent to 0.5 on the Mc Farland standard diluted 100 times on a nutrient broth was used, after which the concentration of the microorganism in it was approximately $10^{6} \mathrm{CFU} / \mathrm{ml}$. $0.5 \mathrm{ml}$ of inoculum was injected into each test tube containing $0.5 \mathrm{ml}$ of the appropriate dilution of the test substance and into one test tube containing $0.5 \mathrm{ml}$ of the nutrient broth without the test drug ("negative" control). The final concentration of the microorganism in each test tube reached the requirements - approximately $5 \cdot 10^{5} \mathrm{CFU} / \mathrm{ml}$. The test tubes were sealed with sterile cotton gauze plugs, test tube test tubes, except "negative" control for the test tube, incubated in a normal atmosphere at $37^{\circ} \mathrm{C}$ for 24 hours. The "negative" control tube was placed in a refrigerator at $+4^{\circ} \mathrm{C}$, where the results were stored.

To determine the presence of microorganism growth, tubes with inoculate were reviewed in transmitted light. In addition, further research on aerococci properties grown on media with the addition of study drugs and without them was conducted.

Under the normal distribution law, the indicators are represented as an arithmetic average (M), a standard error of the average (m). Comparison of statistical characteristics of different groups and dynamics observation was conducted using parametric and nonparametric criteria: assessment of the likelihood difference means for unrelated samples by Mann-Whitney (U), connected to multiple comparison - ANOVA with post-hoc analysis based on the Scheffe test and Dunnett test. The probability of differences in relative quantities is according to Fisher's exact two-tailed criterion (Fisher exact $P$, two-tailed). Statistically significant differences were considered when $\mathrm{P}<0.05$.

\section{Results}

Miramistin and boric acid were found to meet the necessary criteria in addition to norfloxacin in previous experiments. In the further experiment, the minimum inhibitory concentrations (MICs) of drugs that suppressed the CPF growth and did not show a negative effect on A. viridans were determined by serial dilutions. Results of the norfloxacin study are presented in Table 1. Norfloxacin in a dosage of 12.5$50.0 \mu \mathrm{g} / \mathrm{ml}$ effectively inhibited the growth of the CPF, but also decrea- sed the number of aerococci. The dose of $8.3 \mu \mathrm{g} / \mathrm{ml}$ met the criteria we needed, namely suppressing the growth of the CPF and not affecting aerococci. However, it was alarming that the dose of norfloxacin $6 \mu \mathrm{g} / \mathrm{ml}$ left a viable UPPF of $10^{3}-10^{4} \mathrm{CFU} / \mathrm{ml}$. To prevent the emergence of resistant to norfloxacin CPF strains when cultivating aerococci, as well as to enhance the action of the latter, attention was drawn to preparations of surface-active substances with bactericidal and fungicidal properties, safe and widely used in medical practice (miramistin and boric acid). In addition, no data were found on the resistance of microorganisms to these substances. It turned out that the sensitivity of the CPF to the aforementioned substances is different in the strength and spectrum of bactericidal action. The optimal concentrations of these substances that suppressed the growth of the CPF and did not affect the growth of aerococci were determined (Table 2,3).

\section{Table 1}

Influence of norfloxacin on the opportunistic microflora and multibiotopic $A$. viridans co-cultivation $(\mathrm{n}=5$; number of microorganisms after 24 hours of cultivation, $\mathrm{M} \pm \mathrm{m}$ )

\begin{tabular}{|c|c|c|c|c|c|}
\hline \multirow{2}{*}{$\begin{array}{l}\text { Microorganisms } \\
(7 \mathrm{lg} \text { CFU/ml })\end{array}$} & \multicolumn{5}{|c|}{ Dosage of the preparation, $\mu \mathrm{g} / \mathrm{ml}$} \\
\hline & 6.0 & 8.3 & 12.5 & 25.0 & 50.0 \\
\hline $\begin{array}{l}\text { Aerococcus viridans E34 } \\
\text { (human intestine) }\end{array}$ & $\begin{array}{c}6.60 \pm \\
0.16\end{array}$ & $\begin{array}{c}6.36 \pm \\
0.11\end{array}$ & $\begin{array}{c}6.18 \pm \\
0.12\end{array}$ & $\begin{array}{l}5.18 \pm \\
0.12^{* *}\end{array}$ & $\begin{array}{l}3.32 \pm \\
0.15^{* *}\end{array}$ \\
\hline $\begin{array}{l}\text { Aerococcus viridans } O 36 \\
\text { (human oral cavity) }\end{array}$ & $\begin{array}{c}6.56 \pm \\
0.16\end{array}$ & $\begin{array}{c}6.48 \pm \\
0.07\end{array}$ & $\begin{array}{l}5.37 \pm \\
0.10^{* *}\end{array}$ & $\begin{array}{l}3.10 \pm \\
0.10^{* *}\end{array}$ & $\begin{array}{c}2.96 \pm \\
0.13\end{array}$ \\
\hline Aerococcus viridans & $6.30 \pm$ & $6.46 \pm$ & $5.31 \pm$ & $5.16 \pm$ & $3.40 \pm$ \\
\hline 5 м2015 (mouse feces) & 0.09 & 0.07 & $0.09 * *$ & $0.10^{*}$ & $0.11^{* *}$ \\
\hline Aerococcus viridans & $6.62 \pm$ & $6.46 \pm$ & $5.04 \pm$ & $3.45 \pm$ & $3.20 \pm$ \\
\hline $3 \kappa 2015$ (rat feces) & 0.04 & 0.06 & $0.13 * *$ & $0.12^{* *}$ & 0.14 \\
\hline $\begin{array}{l}\text { Aerococcus viridans } 23 \\
\text { (human tonsils) }\end{array}$ & $\begin{array}{c}6.53 \pm \\
0.08\end{array}$ & $\begin{array}{c}6.42 \pm \\
0.12\end{array}$ & $\begin{array}{l}5.34 \pm \\
0.10^{* *}\end{array}$ & $\begin{array}{l}3.37 \pm \\
0.10^{* *}\end{array}$ & $\begin{array}{c}3.05 \pm \\
0.17\end{array}$ \\
\hline $\begin{array}{l}\text { Staphylococcus } \\
\text { aureus }\end{array}$ & $\begin{array}{c}3.31 \pm \\
0.09\end{array}$ & * & - & -- & - \\
\hline $\begin{array}{l}\text { Klebsiella } \\
\text { pneumoniae }\end{array}$ & $\begin{array}{c}4.62 \pm \\
0.11\end{array}$ & $-z_{*}^{*}$ & - & -- & - \\
\hline $\begin{array}{l}\text { Escherichia } \\
\text { coli }\end{array}$ & $\begin{array}{c}3.57 \pm \\
0.04\end{array}$ & $-\ldots * *$ & - & -- & - \\
\hline $\begin{array}{l}\text { Pseudomonas } \\
\text { aeruginosa }\end{array}$ & $\begin{array}{c}4.71 \pm \\
0.11\end{array}$ & --** & - & - & - \\
\hline
\end{tabular}

Note: $*-\mathrm{P}<0.05 ; * *-\mathrm{P}<0.001$ compared to the previous dosage of the drug (Scheffe's criterion).

As shown by the analysis of the data obtained (Table 2), the concentration of myramistin in the culture medium, which showed a strong depressant effect in relation to the conditionally pathogenic microflora and practically did not affect $A$. viridans, was $50 \mu \mathrm{g} / \mathrm{ml}$. $P$. aeruginosa and $K$. pneumoniae were the most resistant to the investigated drug microorganisms in this concentration. Myramistin at concentration of $75 \mathrm{mg} / \mathrm{ml}$ effectively inhibited all pathogenic microflora, but at the same time reduced the aerococci concentration $\left(10^{3}-10^{4} \mathrm{CFU} / \mathrm{ml}\right)$. In addition, myramistin exhibited a fungicidal effect in relation to $C$. albicans.

Similar results were obtained in the study of the effects of boric acid (Table 3). Boric acid concentration in the culture medium, which had a strong depressant effect on $\mathrm{CPF}$ and practically did not affect $A$. viridans was $50 \mu \mathrm{g} / \mathrm{ml}$. P. aeruginosa and E. coli were the most resistant to the studied drug in this concentration microorganisms. Boric acid at a concentration of $75 \mu \mathrm{g} / \mathrm{ml}$ effectively suppressed all of the CPF, but at the same time lowered the concentration of aerococci $\left(10^{5} \mathrm{CFU} / \mathrm{ml}\right)$. In addition, miramistin and boric acid exhibited fungicidal action against $C$. albicans. All studied aerococcus autosymbionts tolerated even the highest investigated concentrations of myramistin well without losing their properties (morphological, physiological, tinctorial, etc.).

Despite the active antimicrobial effects of the investigated drugs on the CPF, this was not complete in some cases, or inhibited the growth of aerococci at higher doses, so the effect of their rational combination on the CPF was investigated. The results are presented in Table 4. The complex of all three drugs completely suppressed the CPF, which may be due to the summation of antimicrobial effects, with virtually no effect on the aerococci growth. Properties of aerococci grown on the nutrient medium with the studied drugs did not differ from aerococci grown on nutrient media without additives. That is why all these drugs were 
combined into a single antimicrobial complex for the production of modified media for the isolation, cultivation and study of biochemical activity of $A$. viridans microorganisms.

\section{Table 2}

Effect of miramistin on the opportunistic microflora and multibiotopic $A$. viridans co-cultivation ( $\mathrm{n}=5$; number of microorganisms after 24 hours of cultivation ( $\mathrm{Ig} \mathrm{CFU} / \mathrm{ml}, \mathrm{M} \pm \mathrm{m}$ )

\begin{tabular}{lccccc}
\hline \multicolumn{1}{c}{ Microorganisms, } & \multicolumn{5}{c}{ Dosage of the preparation, $\mu \mathrm{g} / \mathrm{ml}$} \\
\cline { 2 - 6 } \multicolumn{1}{c}{10} & 25 & 50 & 75 & 100 \\
\hline Aerococcus viridans & $6.61 \pm$ & $6.54 \pm$ & $6.22 \pm$ & $4.40 \pm$ & $3.42 \pm$ \\
E34 (human intestine) & 0.09 & 0.07 & 0.09 & $0.13^{* *}$ & $0.19^{* *}$ \\
Aerococcus viridans & $6.48 \pm$ & $6.37 \pm$ & $5.31 \pm$ & $3.17 \pm$ & $2.77 \pm$ \\
O36 (human oral cavity) & 0.14 & 0.10 & $0.15^{* *}$ & $0.12^{* *}$ & 0.10 \\
Aerococcus viridans & $6.57 \pm$ & $6.53 \pm$ & $5.31 \pm$ & $3.43 \pm$ & $3.08 \pm$ \\
5m2015 (mouse feces) & 0.08 & 0.11 & $0.13^{* *}$ & $0.06^{* *}$ & 0.15 \\
Aerococcus viridans & $6.63 \pm$ & $6.61 \pm$ & $6.64 \pm$ & $4.57 \pm$ & $3.40 \pm$ \\
3k2015 (rat feces) & 0.09 & 0.12 & 0.11 & $0.08^{* *}$ & $0.06^{* *}$ \\
Aerococcus viridans 23 & $6.80 \pm$ & $6.63 \pm$ & $5.48 \pm$ & $3.30 \pm$ & $3.47 \pm$ \\
(human tonsils) & 0.09 & 0.05 & $0.08^{* *}$ & $0.14^{* *}$ & 0.13 \\
Staphylococcus aureus & $3.31 \pm$ & $0.86 \pm$ & $--* *$ & - & - \\
& 0.09 & $0.13^{* *}$ & & & \\
Klebsiella pneumoniae & $4.52 \pm$ & $2.37 \pm$ & $1.17 \pm$ &.$- * *$ & - \\
& 0.09 & $0.10^{* *}$ & $0.12^{* *}$ & & \\
Escherichia coli & $3.53 \pm$ & $-{ }^{* *}$ & - & - & - \\
Pseudomonas & 0.11 & & & & \\
aeruginosa & $4.71 \pm$ & $2.31 \pm$ & $1.02 \pm$ & $--* *$ & - \\
Aerococcus viridans & 0.18 & $0.15^{* *}$ & $0.08^{* *}$ & & \\
E34 (human intestine) & $4.48 \pm$ & $2.16 \pm$ & $--* *$ & - & - \\
\hline
\end{tabular}

Note: see Table 1 .

\section{Discussion}

Selective antimicrobial additives are widely used to prepare nutrient media in microbiology for the cultivation of various microorganisms. Korean researchers Chon et al. (2014) have been successfully used polymyxin as a selective additive for the cultivation of Bacillus cereus. British scientists Hill et al. (2013) achieved good results in isolating C. difficile from environmental objects using cefoxitin-cycloserin-egg yolk agar with lysozyme.
Table 3

Effect of boric acid on the opportunistic microflora and multibiotopic $A$. viridans ( $\mathrm{n}=5$; number of microorganisms after 24 hours of cultivation (Ig CFU/ml, $\mathrm{M} \pm \mathrm{m}$ )

\begin{tabular}{|c|c|c|c|c|c|}
\hline \multirow{2}{*}{$\begin{array}{l}\text { Microorganisms } \\
(7 \mathrm{lg} \text { CFU/ml) }\end{array}$} & \multicolumn{5}{|c|}{ Dosage of the drug, $\mu \mathrm{g} / \mathrm{ml}$} \\
\hline & 10 & 25 & 50 & 75 & 150 \\
\hline Aerococcus viridans & $6.49 \pm$ & $6.38 \pm$ & $6.22 \pm$ & $5.08 \pm$ & $3.32 \pm$ \\
\hline E34 (human intestine) & 0.09 & 0.12 & 0.09 & $0.10^{*}$ & $0.15^{*}$ \\
\hline Aerococcus viridans & $6.61 \pm$ & $6.54 \pm$ & $6.38 \pm$ & $5.16 \pm$ & $3.52 \pm$ \\
\hline O36 (human oral cavity) & 0.06 & 0.07 & 0.12 & $0.10^{*}$ & $0.09 *$ \\
\hline Aerococcus viridans & $6.59 \pm$ & $6.48 \pm$ & $6.40 \pm$ & $5.32 \pm$ & $3.50 \pm$ \\
\hline $5 \mathrm{~m} 2015$ (mouse feces) & 0.15 & 0.12 & 0.13 & $0.11 *$ & $0.08 *$ \\
\hline Aerococcus viridans & $6.48 \pm$ & $6.46 \pm$ & $6.31 \pm$ & $5.19 \pm$ & $3.43 \pm$ \\
\hline 3k2015 (rat feces) & 0.08 & 0.07 & 0.15 & $0.12 *$ & $0.13^{*}$ \\
\hline Aerococcus viridans 23 & $6.61 \pm$ & $6.52 \pm$ & $6.42 \pm$ & $5.30 \pm$ & $3.36 \pm$ \\
\hline (human tonsils) & 0.06 & 0.13 & 0.12 & $0.13 *$ & $0.11^{*}$ \\
\hline Staphylococcus aureus & $\begin{array}{c}3.31 \pm \\
0.15\end{array}$ & _** & -- & - & -- \\
\hline Klebsiella pneumoniae & $\begin{array}{c}4.43 \pm \\
0.09\end{array}$ & $\begin{array}{l}2.49 \pm \\
0.05^{*}\end{array}$ & $\ldots$ & - & - \\
\hline Escherichia coli & $\begin{array}{c}4.48 \pm \\
0.08\end{array}$ & $\begin{array}{c}2.47 \pm \\
0.15^{*}\end{array}$ & $\begin{array}{l}1.08 \pm \\
0.10^{*}\end{array}$ & _-* & - \\
\hline $\begin{array}{l}\text { Pseudomonas } \\
\text { aeruginosa }\end{array}$ & $\begin{array}{c}4.60 \pm \\
0.08\end{array}$ & $\begin{array}{c}2.40 \pm \\
0.11^{*}\end{array}$ & $\begin{array}{l}1.12 \pm \\
0.07^{*}\end{array}$ & -_* & - \\
\hline $\begin{array}{l}\text { Aerococcus viridans } \\
\text { E34 (human intestine) }\end{array}$ & $\begin{array}{c}2.48 \pm \\
0.08\end{array}$ & _.* & 0.07 & - & -- \\
\hline
\end{tabular}

Note: see Table 1 .

In the absence of commercially available selective agents designed to isolate certain microorganisms, it is possible to use media with selective factors, including antibiotics. One study (Glass et al., 2009) evaluated the sensitivity and selectivity of four media for the isolation of Burkholderia mallei and B. pseudomallei (Ashdown agar - a special selective medium for isolation of $B$. pseudomallei, well described in the literature but not commercially available; three commercially available media: Burkholderia cepacia selective agar (BCSA), oxidation-fermentative-polymyxin B-bacitracin-lactose (OFPBL) agar and Pseudomonas cepacia (PC) agar for isolation of B. cepacia). The authors came to the conclusion that Ashdown agar was the most sensitive medium for the isolation of $B$. pseudomallei, but it was unable to support the growth of $B$. mallei. The Czech authors Bunesova at al. (2015) successfully used environments supplemented by mupirocin to isolate and identify Bifidobacterium.

Table 4

Influence of norfloxacin, myramystine and boric acid on opportunistic microflora and A. viridans $(\mathrm{n}=5, \mathrm{M} \pm \mathrm{m})$

\begin{tabular}{|c|c|c|c|c|c|c|}
\hline Drug & $\begin{array}{c}\text { Aerococcus } \\
\text { viridanssymbionts } \\
(7 \mathrm{lgCFU} / \mathrm{ml})\end{array}$ & $\begin{array}{c}\text { Staphylococcus } \\
\text { aureus }(7 \text { lgCFU/ml) }\end{array}$ & $\begin{array}{c}\text { Klebsiella } \\
\text { pneumoniae } \\
\text { (7 lgCFU/ml) }\end{array}$ & $\begin{array}{c}\text { Escherichia coli } \\
\text { (7 } \operatorname{lgCFU} / \mathrm{ml})\end{array}$ & $\begin{array}{c}\text { Pseudomonas } \\
\text { aeruginosa } \\
(7 \mathrm{lgCFU} / \mathrm{ml})\end{array}$ & $\begin{array}{l}\text { Candida albicans } \\
(7 \mathrm{lgCFU} / \mathrm{ml})\end{array}$ \\
\hline Norfloxacin, $8.3 \mu \mathrm{g} / \mathrm{ml}$ & $6.43 \pm 0.06$ & - & $-^{*}$ & \# & -*\# & - \\
\hline Miramistin, $50 \mu \mathrm{g} / \mathrm{ml}$ & $6.46 \pm 0.07$ & - & $1.17 \pm 0.12$ & \# & $1.02 \pm 0.08$ & - \\
\hline Boric acid, $50 \mu \mathrm{g} / \mathrm{ml}$ & $6.40 \pm 0.06$ & - & $-*$ & $1.08 \pm 0.10$ & $1.12 \pm 0.07$ & - \\
\hline Norfloxacin + Miramistin + boric acid & $6.41 \pm 0.11$ & - & $-^{*}$ & \# & $-* \#$ & - \\
\hline
\end{tabular}

Notes: * $\mathrm{P}<0.001$ relative to the corresponding indicator when using miramistin at a dose of $50 \mu \mathrm{g} / \mathrm{ml} ; \#-\mathrm{P}<0.001$ relative to the corresponding indicator for using boric acid at a dose of $50 \mu \mathrm{g} / \mathrm{ml}$ (Scheffer criterion).

In another study (Vlková et al., 2015) a new selective medium with mupirocin, acetic acid and norfloxacin was proposed and evaluated. Among other things, the authors sought to identify an antibiotic that would suppress the growth of clostridia and allow the growth of bifidobacteria, as well as use of the identified substance to develop a selective culture for the cultivation of bifidobacteria. The susceptibility of bifidobacteria and clostridia to 12 antibiotics was tested on an agar by disk diffusion method. Only norfloxacin inhibited the growth of clostridia and did not affect the growth of bifidobacteria. Using both pure cultures and fecal specimens from infants, adults, calves, lambs and piglets, the optimal concentration of norfloxacin in hard growth media was determined as $0.2 \mathrm{mg} / \mathrm{ml}$. The results showed that a hard medium containing norfloxacin $(0.2 \mathrm{mg} / \mathrm{ml})$ in combination with mupirocin $(0.1 \mathrm{mg} / \mathrm{ml})$ and acetic acid $(0.001 \mathrm{ml} / \mathrm{ml})$, is suitable for the isolation of bifidobacteria from fecal specimens of various origins. The authors recommend norfloxacin as a selective factor that inhibits the growth of fecal clostridia. Well-known selective media for the isolation of Fusobacterium spp. from clinical material include josamycin, vancomycin and norfloxacin
(JVN) $(3,4$, and 1 microgram per ml, respectively) as selective agents, plus 5\% defibrinated horse blood. British researchers (Brazier et al., 1991) have successfully isolated the strains of $F$. naviforme, $F$. nucleatum and $F$. necrophorum from the respiratory membrane of healthy volunteers and $F$. varium and $F$. mortiferum strains from fecal suspensions contaminated by these organisms using JVN medium.

The experimental method (Stepanskyi \& Kremenchutskyi, 2014) made it possible to discover the sensitivity of the $A$. viridans symbionts to fluoroquinolones and determined that norfloxacin at a dosage of $8.3 \mu \mathrm{g} / \mathrm{ml}$ practically did not affect the growth of aerococci and effectively suppresses the CPF. However, it was important to enhance the selective effect of norfloxacin with other antimicrobial agents in order to receive stronger suppression of CPF. Therefore, the purpose of the study was to select a selective antibacterial complex that would suppress the growth of UPMF and would not affect the growth of $A$. viridans, with the possibility to use it for the production of modified media for isolation, cultivation and study of the biochemical activity of $A$. viridans microorganisms. 
The complex of all three drugs completely suppressed the CPF, which may be due to the summation of antimicrobial effects, with virtually no effect on the aerococci growth. Properties of aerococci grown on the nutrient medium with the studied drugs did not differ from aerococci grown on nutrient media without additives. That is why all these drugs were combined into a single antimicrobial complex for the production of modified media for the isolation, cultivation and study of biochemical activity of $A$. viridans microorganisms.

Due to the growing resistance to antibiotics, constant monitoring of the effectiveness of antimicrobial additives, especially antibiotics is clearly needed. The use of these additives as substances to which there are no cases of resistance has obvious advantages. Prior to the creation of an antimicrobial complex for the cultivation of $A$. viridans (norfloxacin $8.3 \mu \mathrm{g} / \mathrm{ml}$, miramistin $50 \mu \mathrm{g} / \mathrm{ml}$, boric acid $50 \mu \mathrm{g} / \mathrm{ml}$ ), we did not find cases of resistance to miramystin or boric acid, which is an unconditional advantage in combination with minimal resistance to norfloxacin and a positive experience with the use of this antibiotic as a selective supplement.

\section{Conclusions}

A complex of all three drugs (norfloxacin, miramistin, boric acid) completely suppresses the conditionally pathogenic microflora, which may be due to the summation of antimicrobial effects, with virtually no effect on the growth of aerococci. An antimicrobial complex with optimal concentrations of substances (norfloxacin $8.3 \mu \mathrm{g} / \mathrm{ml}$, miramistin $50 \mu \mathrm{g} / \mathrm{ml}$, boric acid $50 \mu \mathrm{g} / \mathrm{ml}$ ) which effectively suppresses CPF and does not affect the symbiontic $A$. viridans growth was determined.

\section{References}

Brazier, J. S., Citron, D. M., \& Goldstein, E. J. (1991). Aselective medium for Fusobacterium spp. Journal of Applied Bacteriology, 71(4), 343-346.

Bunesova, V., Musilova, S., Geigerova, M., Pechar, R., \& Rada, V. (2015). Comparison of mupirocin-based media for selective enumeration of Bifidobacteria in probiotic supplements. Journal of Microbiological Methods, 109, 106-109.

Cho, S. Y., \& Chung, D. R. (2017). Infection prevention strategy in hospitals in the era of community-associated methicillin-resistant Staphylococcus aureus in the Asia-Pacific region: A review. Clinical Infectious Diseases, 64(2), S82-S90.

Chon, J. W., Song, K. Y., Kim, H., \& Seo, K. H. (2014). Comparison of 3 selective media for enumeration of Bacillus cereus in several food matrixes. Journal of Food Science, 79(12), 2480-2484.

CLSI (2010). Performance standards for antimicrobial susceptibility testing: 20th informational supplement. CLSI document M100-S20. Clinical and Laboratory Standards Institute, Wayne, PA.

Collins, M. D., Jovita, M. R., Hutson, R. A., \& Ohlén, M. (1999). Aerococcus christensenii sp. nov., from the human vagina. International Journal of Systematic Bacteriology, 49, 1125-1128.

Devriese, L. A., Hommez, J., Laevens, H., Pot, B., Vandamme, P., \& Haesebrouck, F. (1999). Identification of aesculin-hydrolyzing streptococci, lactococci, aerococci, and enterococci from subclinical intramammary infections in dairy cows. Veterinary Microbiology. (70), 87-94.

Facklam, R., \& Elliott, J. A. (1995). Identification, classification, and clinical relevance of catalase-negative, gram-positive cocci, excluding the streptococci and enterococci. Clinical Microbiology, 8, 479-495.

Facklam, R., Lovgren, M., Shewmaker, P. L., \& Tyrrell, G. (2003). Phenotypic description and antimicrobial susceptibilities of Aerococcus sanguinicola isolates from human clinical samples. Journal of Clinical Microbiology, 41(6), 2587-2592.
Glass, M. B., Beesley, C. A., Wilkins, P. P., \& Hoffmaster, A. R. (2009). Comparison of four selective media for the isolation of Burkholderia mallei and Burkholderia pseudomallei. The American Journal of Tropical Medicine and Hygiene, 80(6), 1023-1028.

González Ramallo, V. J., Mirón Rubio, M., Estrada Cuxart, O., \& García Leoni, M.E. (2017). Usefulness of hospital at home in nosocomial infections: Advantages and limitations. Revista Española de Quimioterapia, 30(1), 61-65.

Good, N. E., Winget, G. D., Winter, W., Connolly, T. N., Izawa, S., \& Singh, R. M. (1966). Hydrogen ion buffers for biological research. Biochemistry, 5, 467-477.

Habriev, R. U. (2005). Rukovodstvo po jeksperimental'nomu (doklinicheskomu) izucheniju novyh farmakologicheskih veshhestv [Manual on experimental (preclinical) study of new pharmacological substances]. Medicina, Moscow (in Russian).

Hill, K. A., Collins, J., Wilson, L., Perry, J. D., \& Gould, F. K. (2013). Comparison of two selective media for the recovery of Clostridium difficile from environmental surfaces. Journal of Hospital Infection, 83(2), 164-166.

Humphries, R. M, \& Hindler, J. A. (2014). In vitro antimicrobial susceptibility of Aerococcus urinae. Journal of Clinical Microbiology, (52), 2177-2180.

Kremenchuckij, G. N., Ryzhenko, S. A., Val'chuk, S. I. (2003). Rol' mikrojekologii organizma cheloveka i principy ejo korrekcii [The role of microecology of the human body and the principles of its correction]. Porogi, Dnepropetrovsk (in Russian).

Kremenchuckyj, G. N., Jurgel', L. G., Sharun, O. V., \& Stepans'kyj, D. O. (2009). Metody vydilennja ta identyfikacii' grampozytyvnyh katalazonegatyvnyh kokiv [Methods of selection and identification of gram-positive catalasenegative cocci]. Kyiv (in Ukrainian).

Rasmussen, M. (2013). Aerococci and aerococcal infections. Journal of Infection, 66(6), $467-474$.

Rizhenko, S. A., Chernjaev, S. A., \& Kremenchuc'kij, S. G. (2002). Zmina biologichnyh vlastyvostej useredini populjaciji Aerococcus viridans [Changing biological properties within the population Aerococcus viridans]. Medychni Perspektyvy, 7(2), 18-21 (in Ukrainian)

Saishu, N., Morimoto, K., Yamasato, H., Ozaki, H., \& Murase, T. (2015). Characterization of Aerococcus viridans isolated from milk samples from cows with mastitis and manure samples. Journal of Veterinary Medical, 77(9), 1037-1042.

Senneby, E., Göransson, L., Weiber, S., \& Rasmussen, M. (2016). A populationbased study of aerococcal bacteraemia in the MALDI-TOF MS-era. European Journal of Clinical Microbiology and Infectious Diseases, 35(5), 755-762.

Senneby, E., Petersson, A. C., \& Rasmussen, M. (2015). Epidemiology and antibiotic susceptibility of aerococci in urinary cultures. Diagnostic Microbiology and Infectious Disease, 81(2), 149-151.

Shelton-Dodge, K., Vetter, E. A., Kohner, P. C., Nyre, L. M., \&Patel, R. (2011). Clinical significance and antimicrobial susceptibilities of Aerococcus sanguinocola and Aerococcus urinae. Diagnostic Microbiology and Infectious Disease, 70, 448-451.

Uh, Y., Son, J. S., Jang, I. H., Yoon, K. J., \& Hong, S. K. (2002). Penicillinresistant Aerococcus viridans bacteremia associated with granulocytopenia. Journal of Korean Medical Science, 17, 113-115.

Vlkova, E., Salmonova, H., Bunešova, V., Geigerova, M., Rada, V., \& Musilova, $\breve{S}$. (2015). A new medium containing mupirocin, acetic acid, and norfloxacin for the selective cultivation of bifidobacteria. Anaerobe, 34, 27-33.

Williams, R. E., \& Hirch, S. T. (1953). Cowan Aerococcus - a new bacterial genus. Journal of General Microbiology, 8, 475-480.

Wise, M. G., \& Siragusa, G. R. (2007). Quantitative analysis of the intestinal bacterial community in one- to three-week-old commercially reared broiler chickens fed conventional or antibiotic-free vegetable-based diets. Journal of Applied Microbiology, 102, 1138-1149.

Yasukawa, K., Afzal, Z., Mbang, P., Stager, C. E., \& Musher, D. M. (2014). Aerococcal infection at three US Tertiary Care Hospitals. Southern Medical Journal, 107(10), 642-647 